\title{
Pemuridan Bagi Jemaat Penyandang Disabilitas
}

\author{
Innawati \\ Institut Injil Indonesia \\ innawati.t@gmail.com
}

\begin{abstract}
The church must play an active role in society by empowering its congregation, without exception the marginalized - persons with disabilities; who should have the same rights and opportunities, as well as equal treatment; empowered and involved in the ministry of the church, giving meaning to the lives of others and himself to the glory of God. It was undeniable that persons with disabilities experience discrimination in various fields of life, including church services. The research method used was qualitative; conducted in-depth and open observations, focused interviews, and selected interviews with selected informants. The research objective was to find a model of discipleship for congregations with disabilities in the $M$ Malang Church. The findings of the research suggest that the model of discipleship in the M Malang church was a combination of equipping through teaching Christian values, building attitudes, and empowering the congregation. The pastor prioritizes empowerment with mission trip activities as a model of discipleship for congregations with disabilities.
\end{abstract}

Keywords: Discipleship; Empowerment; Disabilities

\begin{abstract}
Abstrak
Gereja harus berperan aktif di dalam masyarakat dengan memberdayakan jemaatnya, tanpa kecuali kaum marjinal - penyandang disabilitas; yang seyogyanya mendapat hak dan kesempatan yang sama, serta perlakuan yang setara; diberdayakan dan terlibat dalam pelayanan gereja, memberi arti bagi kehidupan orang lain dan dirinya sendiri bagi kemuliaan Allah. Tidak dapat dipungkiri bahwa penyandang disabilitas mengalami diskriminasi dalam berbagai bidang kehidupan, tidak terkecuali, juga di dalam pelayanan gereja. Metode penelitian yang digunakan kualitatif; melakukan observasi, wawancara terfokus dan wawancara terpilih terhadap informan yang terpilih secara mendalam dan terbuka. Tujuan penelitian adalah untuk menemukan model pemuridan bagi jemaat penyandang disabilitas di Gereja M Malang. Temuan hasil penelitian mengemukakan bahwa model pemuridan di gereja M Malang adalah kombinasi dari pembekalan melalui pengajaran nilai-nilai Kristen, pembinaan sikap, serta pemberdayaan jemaatnya. Gembala mengutamakan pemberdayaan dengan kegiatan mission trip sebagai model pemuridan bagi jemaat penyandang disabilitas.
\end{abstract}

Kata kunci: Pemuridan; Pemberdayaan; Penyandang disabilitas 


\section{PENDAHULUAN}

Salah satu masalah sosial adalah tentang penyandang disabilitas, karena ada pernyataan bahwa disabilitas adalah salah satu penyebab kemiskinan di Indonesia. $^{1}$ Blair menuliskan bahwa penyandang disabilitas mengalami kerugian dalam banyak aspek kehidupan sehari-hari dibandingkan dengan nondisabilitas.

Penyandang disabilitas adalah: lebih cenderung dalam keadaan miskin pendapatan penyandang disabilitas, ratarata, kurang dari setengah yang diperoleh oleh non-disabilitas; kecil kemungkinannya memiliki kualifikasi pendidikan - penyandang disabilitas lebih cenderung tidak memiliki kualifikasi pendidikan; lebih cenderung tidak aktif secara ekonomi - hanya satu dari dua penyandang disabilitas usia kerja yang saat ini bekerja, dibandingkan dengan empat dari lima orang bukan penyandang disabilitas; lebih mungkin mengalami masalah dengan kejahatan rasial atau pelecehan - seperempat dari semua penyandang disabilitas mengatakan bahwa mereka pernah mengalami kejahatan rasial atau pelecehan, dan jumlah ini meningkat menjadi $47 \%$ dari

1 Kompasiana, "Disabilitas Merupakan Sebab Dan Akibat Dari Kemiskinan," REP, 2014, http://sosbud.kompasiana.com/2014/06/14/disabil itas-merupakan-sebab-dan-akibat-darikemiskinan-658544.html. orang-orang dengan kondisi kesehatan mental; lebih mungkin mengalami masalah dengan perumahan - sembilan dari sepuluh keluarga dengan anak-anak cacat memiliki masalah dengan tempat mereka tinggal; lebih mungkin mengalami masalah dengan transportasi masalah yang paling sering dialami oleh penyandang cacat sebagai tantangan terbesar mereka. ${ }^{2}$

Ini adalah juga realita penyandang disabilitas di Indonesia, mengalami perlakuan diskriminatif dalam bidang ekonomi, sosial, politik, pendidikan, pelayanan kesehatan, hukum, budaya, ketenagakerjaan, dan saranaprasarana. Penelitian Riwukore, Habaora, Susanto, dan Manafe menemukan bahwa penyandang disabilitas mendapat perlakuan diskriminasi dan stereotype secara sosial, biomedis dan biopsikososial. Mereka perlu dilindungi hak-haknya dan diberdayakan. ${ }^{3}$ Widhawati, Santoso, dan Apsari mengemukakan bahwa pemerintah telah mengeluarkan undang-undang untuk melindungi penyandang disabilitas di dunia kerja formal, tetapi pelaksanaannya menemui kendala disebabkan adanya

\footnotetext{
2 Tony Blair, Improving The Life Chances Of Disabled People, 2005.

3 Jefirstson Richset Riwukore et al., "Persepsi Publik Terhadap Penyandang Disabilitas Di Kota Kupang Provinsi Nusa Tenggara Timur," Journal of Chemical Information and Modeling (2019).
} 
aturan kuota penerimaan bagi mereka. ${ }^{4}$

Riset Dini Widinarsih mengkonfirmasi adanya perlakuan diskriminatif pada para penyandang disabilitas dalam kehidupan sehari-hari. $^{5}$ Eta Yuni Lestari, Slamet Sumarto dan Noorochmat Isdaryanto juga berpendapat bahwa mereka mendapat diskriminasi hak dalam pekerjaan, pendidikan, tempat ibadah, tempat hiburan, transportasi dan hukum. ${ }^{6}$

Setiap anggota keluarga Tubuh Kristus, berhak mendapat perlakuan yang sama dan setara dalam proses pemuridan. Pemuridan bersifat multikultural dan berkesinambungan; seseorang yang dimuridkan, suatu hari dituntut mampu memuridkan orang lain. ${ }^{7}$ Untuk mewujudkan dan melaksanakan amanat agung dalam Matius 28:19-20, dengan menggerakkan jemaat melakukan kegiatan misi diperlukan pemuridan secara misioner. ${ }^{8}$ Pemberdayaan jemaat

${ }^{4}$ Monica Kristiani Widhawati, Meilanny Budiarti Santoso, and Nurliana Cipta Apsari, "RUANG KERJA INKLUSIF BAGI TENAGA KERJA DENGAN DISABILITAS FISIK," EMPATI: Jurnal Ilmu Kesejahteraan Sosial (2020).

${ }^{5}$ Dini Widinarsih, "PENYANDANG DISABILITAS DI INDONESIA :," JURNAL ILMU KESEJAHTERAAN SOSIAL (2019).

${ }^{6}$ Eta Yuni Lestari. Slamet Sumarto. Noorochmat Isdaryanto, "Pemenuhan Hak Bagi Penyandang Disabilitas Di Kabupaten Semarang Melalui Implementasi Convention on the Rights of Persons With Disabillities (Cprd) Dalam Bidang Pendidikan," Integralistik (2017).

7 I Putu Ayub Darmawan, "Jadikanlah Murid: Tugas Pemuridan Dan Gereja Menurut Matius 28:18-20," Evangelikal: Jurnal Teologi Injili dan Pembinaan Warga Jemaat (2019).

8 Tri Subekti, "Pemuridan Misioner harus dijalankan oleh gereja secara bersamaan dalam pimpinan Roh Kudus yang pada akhirnya membuat usaha untuk memenangkan jiwa berlangsung secara efektif. ${ }^{9}$ Pemberdayaan jemaat gereja secara holistik mampu melakukan amanat agung Yesus Kristus.

Pada kenyataannya penyandang disabilitas mengalami yang diskriminasi diberbagai bidang kehidupan, tidak terkecuali dalam hal pelayanan dalam gereja. Di dalam masyarakat tidak dapat dipungkiri bahwa terdapat diskriminasi pada penyandang disabilitas, baik di luar gereja maupun di dalam gereja. Seorang tuna netra (penyandang disabilitas) yang memiliki potensi bakat tertentu di sebuah gereja sukar mendapat kesempatan dan cenderung tidak dilibatkan dalam pelayanan gereja. Masyarakat dan bahkan sesama orang Kristen masih belum mempercayai saudara-saudara tuna netranya serta melibatkannya di dalam pelayanan gereja. Masih ada gap, pembedaan, yang membatasi lingkup gerak seorang jemaat penyandang disabilitas di dalam gereja. Bahkan musik gereja pun menunjukkan ketidakberpihakannya kepada

Dalam Menyiapkan Perluasan Gereja Lokal," EPIGRAPHE: Jurnal Teologi dan Pelayanan Kristiani (2019).

${ }^{9}$ Yushak Soesilo, "Pentakostalisme Dan Aksi Sosial: Analisis Struktural Kisah Para Rasul 2:41-47," DUNAMIS: Jurnal Teologi dan Pendidikan Kristiani (2018). 
penyandang disabilitas. Kritsno Saptenno dalam penelitiannya menemukan bahwa musik pop lebih berpihak kepada mereka dibandingkan musik gereja. ${ }^{10}$

Pada umumnya, seorang jemaat penyandang disabilitas Kristen belum diberdayakan di tengah jemaat yang non disabilitas di dalam pelayanan gerejanya sendiri. Hal inilah yang kemudian mendorong berdirinya sebuah komunitas persekutuan doa Kristen penyandang disabilitas di Malang, yang kemudian berkembang menjadi sebuah gereja yaitu gereja M Malang yang beranggotakan jemaat penyandang disabilitas.

Hak penyandang disabilitas memberikan tanggung jawab pada negara dan warganya untuk berperan aktif melindungi kesejahteraan dan kelangsungan hidup para penyandang disabilitas. ${ }^{11}$ Pemerintah belum merevisi UU No. 4/ 1997 mengenai Penyandang Cacat supaya sejalan prinsip HAM, memaksimalkan pengaturan negara terhadap perlindungan bagi penyandang disabilitas dalam segala bidang sesuai dengan cara pandang HAM. $^{12}$ UU ini

10 Kritsno Saptenno, "Mewariskan Keberpihakan Lewat Musik: Suatu Interpretasi Teologis Yang Berpihak Kepada Penyandang Disabilitas Terhadap Lagu 'Fly,"' KENOSIS: Jurnal Kajian Teologi (2019).

11 International Labour (ILO) Organization, "Inklusi Penyandang Disabilitas Di Indonesia,” Jurnal Refleksi Hukum (2017).

12 Sandra Moniaga and Newbie, "Disabilitas, HAM, Dan Gereja," last modified 2018, berisi tentang konsep charity, bukan berpihak pada perwujudan hak asasi manusia dan peningkatan diri penyandang disabilitas. Gereja seyogyanya berpartisipasi aktif mendorong agar hasil revisi UU tersebut terwujud. Salah satu cara mengentas kemiskinan jemaat penyandang disabilitas adalah gereja dan pemerintah dapat melakukan program kerjasama untuk memberdayakan mereka dalam upaya meningkatan kesejahteraan mereka secara holistik. ${ }^{13}$

Spiritualitas adalah aspek penting dalam kehidupan manusia. Hal paling urgen yang harus dilakukan di dalam tubuh Gereja adalah membenahi masalah internalnya, yaitu pemuridan bagi jemaat penyandang disabilitas. Pemuridan adalah inti dari spiritualitas Kristen. ${ }^{14}$ Pemuridan membuat pergerakan dalam sebuah gereja. ${ }^{15}$ Perlakuan diskriminatif pemimpin terhadap jemaat penyandang disabilitas di gereja bisa berakibat pada penghambatan proses penyesuaian diri dan pemuridan yang berdampak pada

https://www.hidupkatolik.com/2018/10/31/28330 /disabilitas-ham-dan-gereja.

${ }^{13}$ George Marthen Likumahwa, John A Titaley, and Steve Gaspersz, "Keluar Dari Kemiskinan: Studi Pembangunan Dan Pemberdayaan Jemaat Di Dusun Siahari, Kecamatan Seram Utara Timur," Arumbae: Jurnal Ilmiah Teologi dan Studi Agama (2020).

14 Thomas V. Frederick, "Discipleship and Spirituality from a Christian Perspective," Pastoral Psychology (2008).

15 Handreas Hartono, "Pentingnya Kurikulum Dalam Pemuridan," Kharismata: Jurnal Teologi Pantekosta (2020). 
kedewasaan iman mereka. ${ }^{16}$

Manusia memiliki potensi yang tidak terbatas dan umumnya belum dikembangkan secara maksimal. ${ }^{17}$ Seorang manusia Kristen dituntut untuk hidup berbuah dan produktif. Untuk hidup produktif, seseorang harus bisa memberdayakan potensinya, dan untuk itu diperlukan kesempatan. Pemuridan adalah salah satu cara Roh Kudus terlibat dalam pergerakan gereja, memerlukan konsep yang diwujudkan dalam tindakan. Jemaat penyandang disabilitas berhak dan harus mendapat kesempatan menjalani proses pemuridan. Jadi tujuan artikel ini untuk menemukan jawaban: "Bagaimanakah Model Pemuridan Bagi Jemaat Penyandang Disabilitas di Gereja M Malang?"

\section{METODE PENELITIAN}

Penelitian ini dilaksanakan di Gereja M Malang dengan menggunakan metode kualitatif, menghasilkan data deskriptif dari individu-individu di tempat penelitian, ditujukan pada latar dan individu secara holistik. ${ }^{18}$ Laporan

16 Geminastiti Purinami A, Nurliana Cipta Apsari, And Nandang Mulyana, "Penyandang Disabilitas Dalam Dunia Kerja," Focus : Jurnal Pekerjaan Sosial (2019).

17 Yoseph P. Bising, "Kebenaran Tentang Hidup Produktif," Kurios Volume: 2, no. No.1 (2014): 57-61.

18 Lexy J. Moleong, Metodologi Penelitian Kualitatif (Bandung: PT Remaja Rosdakarya, 2012). disusun berdasarkan hasil wawancara dan pengamatan lapangan. ${ }^{19}$ Peneliti akan menerapkan langkah-langkah penelitian seperti yang dikemukakan oleh Spradley, yaitu: (1) menyusun pertanyaanpertanyaan berdasarkan subfokus yang merupakan pengembangan dari fokus penelitian. (2) melakukan pengamatan berperan serta/wawancara. (3) melakukan wawancara terfokus. (4) membuat catatan lapangan (CL) dari hasil wawancara dengan informan. (5) analisis taksonomi. (6) wawancara terpilih. (7) analisis komponen dan (8) analisis tema. (9) memaparkan temuan umum dan temuan khusus, dan (10) menuliskan laporan berdasarkan temuan dari semua subfokus penelitian. ${ }^{20}$

\section{HASIL DAN PEMBAHASAN}

Ada dua hal penting yang ditemukan dalam penelitian mengenai pemuridan di gereja komunitas penyandang disabilitas, yaitu:

19 Sonny Eli Zaluchu, "Strategi Penelitian Kualitatif Dan Kuantitatif Di Dalam Penelitian Agama," Evangelikal: Jurnal Teologi Injili dan Pembinaan Warga Jemaat (2020).

20 James P. Spradley, Participant Observation (New York: Holt, Rinehart and Winston, 1980). 


\section{Bidang-Bidang yang Menjadi Fokus Perhatian Dalam Pemuridan}

Dari hasil penelitian ditemukan bahwa bidang-bidang yang menjadi fokus perhatian gembala dalam pemuridan jemaat, yaitu:

Pertama, Pengajaran nilai-nilai kepada Jemaat Gereja M Malang meliputi: Allah Bapa, Yesus Kristus, Roh Kudus, manusia, dosa, keselamatan, dan gereja. Salah satu tujuan program pemuridan di gereja adalah untuk menjadikan jemaat menjadi pembuat murid. Pemuridan bukan hanya supaya jemaat menjadi murid Yesus yang baik saja, melainkan jemaat bersaksi dan memberitakan tentang Yesus bagi sesama. Jika jemaat belum mendapat pengajaran dan pengertian yang benar, mereka sukar bersaksi tentang Yesus Sang Juru Selamat, pemuridan di gereja itu belum bisa dikatakan berhasil.

Kedua, Pembinaan Sikap Jemaat Gereja M Malang, meliputi: menanamkan nilai-nilai kepada jemaat, membina sikap kehidupan doa dan ibadah jemaat, membina sikap taat dan disiplin jemaat, membina sikap-sikap bertobat/mengakui dosa, tahan menghadapi godaan, sikap hidup berkemenangan, mengajarkan jemaat untuk mengerti mengenai sumber kekuatan hidup, mengajarkan kepada jemaat untuk menemukan atau peka terhadap kehendak Allah, membina sikap kerohanian jemaat, membina jemaat penyandang disabilitas dan melakukan penginjilan kepada penyandang disabilitas, memberi konseling pada jemaat, dan melakukan pemuridan. Pembinaan atas hal-hal tersebut di atas membutuhkan selain pengajaran teori juga memerlukan keteladanan hidup dari pemimpinnya. Satu bukti tindakan atau keteladanan dari pemimpin akan sangat berarti dan berdampak bagi jemaat daripada ribuan kata-kata yang disampaikan kepada jemaat. Pemuridan adalah proses pembentukan dua arah, di satu sisi gembala memuridkan jemaatnya; namun pada saat yang bersamaan gembala diasah dan makin diperdalam kedewasaan dan kematangan rohaninya dalam proses pemuridan tersebut. Proses pemuridan menuntut praktik karena ajaran Kristus tentang kehidupan orang percaya yang telah menerima Yesus Kristus adalah sebuah praktik kehidupan, pembaharuan hidup, bukan teori yang cukup dihafalkan saja.

Ketiga, Pemberdayaan Jemaat Gereja M Malang, meliputi: mendorong jemaat berani bersaksi bagi Kristus dan terlibat di dalam pelayanan, mendorong jemaat bekerja dan memberikan pelatihan-pelatihan kepada jemaat. Pemberdayaan, adalah proses melibatkan 
seseorang berperan dalam melaksanakan gagasan-gagasan kerja di masyarakat (atau gereja). ${ }^{21}$ Pemberdayaan juga mempunyai arti kata yang sama dengan proses pengembangan masyarakat (jemaat), yang secara umum kata ini diartikan sebagai usaha untuk memajukan kehidupan masyarakat (gereja) dan warganya (jemaatnya). ${ }^{22}$ Dalam proses pengembangan tersebut, seorang pemimpin masyarakat harus memperhatikan aspek ekonomi dan lingkungan untuk secara bersinergi ditingkatkan.

\section{Cara-cara yang Diterapkan Dalam Pemuridan}

Dari 26 domain, penelitian ini menemukan ada 21 cara (Lihat Tabel.1) yang dilakukan dalam pemuridan di gereja tersebut. Ada dua cara yang sering dilakukan gembala dalam pemuridan jemaat, yakni: menjelaskan (termasuk menerangkan dan mengajarkan), dan mengingatkan (termasuk menyadarkan dan menasehati). Sedangkan cara-cara lain jarang dilakukan oleh gembala. Jika diperhatikan, kedua cara pemuridan gembala kepada jemaatnya tersebut,

21 Jim Ife and Frank Tesoriero, Community Development (Yogyakarta: Pustaka Belajar, 2008),13.

22 Arif Budiman, Teori Pembangunan Dunia Ketiga (Jakarta: PT Gramedia Pustaka Utama, 2000), 1 . berorientasi kepada gembalanya. Ditinjau dari orientasi kegiatan, gembala yang sangat dominan dalam melaksanakan pemuridan. Jemaat lebih dianggap sebagai obyek pemuridan daripada subyek pemuridan. Ditinjau dari interaksi, komunikasi tidak berimbang, hanya dari gembala kepada jemaat. Jemaat bersikap pasif dan mendengarkan tanpa dapat mengeluarkan pendapat, bertanya dan bertukar pikiran. Khususnya dalam kebutuhan konseling atau pelayanan pribadi kurang terpenuhi atau terabaikan.

Bagian ini berisi data dan penjelasan dari hasil penelitian yang ditemukan. Penyajian hasil penelitian dapat dibangun dengan membandingkan pendapat, pandangan, atau temuan penelitian yang sudah ada, baik yang kontradiktif maupun yang sesuai dengan hasil penelitian. 
Tabel 1:

Frekuensi Penggunaan Cara Dalam Pemuridan Jemaat Gereja M Malang

\begin{tabular}{|c|c|c|c|c|c|}
\hline No & Cara Yang Dilakukan & Frekuensi & & $\%$ & Keterangan \\
\hline 1 & Menjelaskan, menerangkan, mengajarkan & 62 & frekuensi atau & 57.9 & $\overline{\text { Sering }}$ \\
\hline 2 & Mengingatkan, menyadarkan, menasehati & 15 & frekuensi atau & 14.0 & Sering \\
\hline 3 & Memotivasi, mendorong & 8 & frekuensi atau & 7.5 & Jarang \\
\hline 4 & Melakukan & 7 & frekuensi atau & 6.5 & $\overline{\text { Jarang }}$ \\
\hline 5 & Menyuruh & 7 & frekuensi atau & 6.5 & Jarang \\
\hline 6 & Menghimbau, menyarankan & 5 & frekuensi atau & 4.7 & $\overline{\text { Jarang }}$ \\
\hline 7 & Memahami & 5 & frekuensi atau & 4.7 & $\overline{\text { Jarang }}$ \\
\hline 8 & Memberi contoh & 4 & frekuensi atau & 3.7 & $\overline{\text { Jarang }}$ \\
\hline 9 & Memberi pelatihan & 4 & frekuensi atau & 3.7 & Jarang \\
\hline 10 & Tinggal berkelompok & 3 & frekuensi atau & 2.8 & Jarang \\
\hline 11 & Menekankan, mengarahkan & 3 & frekuensi atau & 2.8 & Jarang \\
\hline 12 & Melibatkan & 2 & frekuensi atau & 1.9 & Jarang \\
\hline 13 & Memberi kesempatan & 2 & frekuensi atau & 1.9 & $\overline{\text { Jarang }}$ \\
\hline 14 & Membangun relasi & 1 & frekuensi atau & 0.9 & $\overline{\text { Jarang }}$ \\
\hline 15 & Memberi kepercayaan & 1 & frekuensi atau & 0.9 & $\overline{\text { Jarang }}$ \\
\hline 16 & Memperlakukan & 1 & frekuensi atau & 0.9 & $\overline{\text { Jarang }}$ \\
\hline 17 & Mendengarkan & 1 & frekuensi atau & 0.9 & $\overline{\text { Jarang }}$ \\
\hline 18 & Mendoakan & 1 & frekuensi atau & 0.9 & $\overline{\text { Jarang }}$ \\
\hline 19 & Mengajak & 1 & frekuensi atau & 0.9 & $\overline{\text { Jarang }}$ \\
\hline 20 & Mengunjungi & 1 & frekuensi atau & 0.9 & $\overline{\text { Jarang }}$ \\
\hline 21 & Pendekatan pribadi & 1 & frekuensi atau & 0.9 & $\overline{\text { Jarang }}$ \\
\hline & Jumlah & 135 & & 100 & \\
\hline
\end{tabular}

Dari temuan terdapat total 135 tindakan pemuridan. Pelakunya adalah pemimpin (gembala) dan pengurus gereja. Pemimpin dan pengurus bersamasama melakukan 47 tindakan, pemimpin sendiri melakukan 82 tindakan dan pengurus sendiri melakukan 6 tindakan.

Jadi berdasarkan data tersebut dapat disimpulkan bahwa pemimpin lebih dominan dari pada pengurus dalam proses pemuridan jemaat di gereja tersebut (Tabel. 2). 
Tabel 2:

Data Keterlibatan Pemimpin Dan Pengurus Dalam Pemuridan Jemaat Gereja M Malang

\begin{tabular}{|c|c|c|c|c|c|}
\hline \multirow[b]{2}{*}{ No } & \multirow[b]{2}{*}{ Bidang Yang Menjadi Fokus Pemuridan } & \multirow[b]{2}{*}{$\begin{array}{l}\text { Banyaknya } \\
\text { Tindakan }\end{array}$} & \multicolumn{3}{|c|}{ Pelaku } \\
\hline & & & Pemimpin & Pengurus & $\begin{array}{l}\text { Pemimpin dan } \\
\text { Pengurus }\end{array}$ \\
\hline \multirow[t]{8}{*}{1} & Pengajaran PA Jemaat Gereja M Malang & & & & \\
\hline & 1.1. Cara mengajarkan tentang Allah Bapa. & 4 & & & 4 \\
\hline & 1.2. Cara mengajarkan tentang Yesus Kristus & 5 & & & 5 \\
\hline & 1.3. Cara mengajarkan tentang Roh Kudus & 2 & & & 2 \\
\hline & 1.4. Cara mengajarkan tentang manusia & 7 & & & 7 \\
\hline & 1.5. Cara mengajarkan tentang dosa & 4 & & & 4 \\
\hline & 1.6. Cara mengajarkan tentang keselamatan & 4 & & & 4 \\
\hline & 1.7. Cara mengajarkan tentang gereja & 2 & & & 2 \\
\hline \multirow[t]{16}{*}{2} & Pembinaan Jemaat Gereja M Malang & & & & \\
\hline & 2.1. Cara menanamkan nilai-nilai kepada jemaat & 4 & & & 4 \\
\hline & 2.2. Cara membina jemaat penyandang disabilitas & 2 & & & 2 \\
\hline & 2.3. Cara membina sikap kehidupan doa & 7 & 7 & & \\
\hline & 2.4. Cara membina sikap kehidupan ibadah & 3 & 3 & & \\
\hline & 2.5. Cara membina sikap taat & 9 & 9 & & \\
\hline & 2.6. Cara membina sikap disiplin & 2 & 1 & 1 & \\
\hline & $\begin{array}{l}\text { 2.7. Cara membina sikap yang mau bertobat/mengakui } \\
\text { dosa }\end{array}$ & 3 & 3 & & \\
\hline & 2.8. Cara membina sikap menghadapi godaan & 4 & 3 & 1 & \\
\hline & 2.9. Cara membina sikap hidup berkemenangan & 14 & 13 & 1 & \\
\hline & $\begin{array}{l}\text { 2.10. Cara mengajarkan jemaat untuk mengerti } \\
\text { mengenai sumber kekuatan hidup }\end{array}$ & 6 & & & 6 \\
\hline & $\begin{array}{l}\text { 2.11. Cara mengajarkan kepada jemaat untuk } \\
\text { menemukan/peka terhadap kehendak Allah }\end{array}$ & 7 & & & 7 \\
\hline & 2.12. Cara membina sikap kerohanian jemaat & 14 & 12 & 2 & \\
\hline & 2.13. Cara penginjilan kepada penyandang disabilitas & 6 & 6 & & \\
\hline & 2.14. Cara memberi konseling pada jemaat & 2 & 1 & 1 & \\
\hline & 2.15. Cara melakukan pemuridan pada jemaat & 4 & 4 & & \\
\hline \multirow[t]{6}{*}{3} & Pemberdayaan Jemaat Gereja M Malang & & & & \\
\hline & 3.1. Mendorong jemaat berani bersaksi bagi Kristus & 6 & 6 & & \\
\hline & 3.2. Mendorong jemaat terlibat di dalam pelayanan & 8 & 8 & & \\
\hline & 3.3. Mendorong jemaat bekerja & 2 & 2 & & \\
\hline & 3.4. Memberikan pelatihan-pelatihan kepada jemaat & 4 & 4 & & \\
\hline & Jumlah & 135 & 82 & 6 & 47 \\
\hline
\end{tabular}


Melalui tahapan pengamatan terfokus dan analisis taksonomi peneliti menemukan sejumlah domain. Dari domain yang terorganisir ini dijumpai beberapa tema menarik yaitu:

Pertama yang ditemukan dari Gereja M Malang, yang hendak ditekankan atau ditonjolkan adalah ciri tuna netranya (penyandang disabilitasnya). Gereja M adalah gereja komunitas tuna netra, ke depan gereja ini tetap akan mempertahankan dan memegang erat cirinya sebagai gereja komunitas tuna netra (penyandang disabilitas). Sebagai catatan, meski sebagian besar jemaatnya adalah tuna netra dan penyandang disabilitas jenis lain, namun ada juga yang non disabilitas.

Kedua, cara pembinaan bagi jemaat Gereja M Malang satu-satunya adalah melalui khotbah ibadah mingguan dan kelas pengajaran Pendalaman Alkitab (PA) sebulan sekali, yang diberikan oleh coordinator bagian Pengajaran atau mengundang pembicara dari luar. Pembinaan jemaat gereja ini sangat penting bagi pertumbuhan iman dan pembentukan karakter jemaat. Gereja adalah salah satu wadah untuk pendidikan karakter manusia Indonesia. Pendidikan karakter ini bisa dilakukan melalui pemuridan. Menurut pengamatan peneliti, pengajaran di tempat ini bisa ditingkatkan.

Ketiga, komisi-komisi gereja dan pengurus yang sudah terbentuk selama sepuluh bulan lebih ini masih belum seluruhnya menjalankan fungsinya dengan baik. Ini berkaitan dengan kepemimpinan gembala yang cenderung otoriter.

Kepemimpinan berbicara tentang tanggungjawab dan tindakan dalam menjalankan peran, dari ada sekedar posisi dan jabatan. Optimalisasi kepemimpinan seorang gembala lebih menentukan keberhasilan pelayanan di suatu gereja dibandingkan program atau sumber dayanya. Terhambatnya fungsifungsi pelayanan di suatu gereja bisa disebabkan oleh tidak berfungsinya peran-peran kepemimpinan di gereja tersebut. $^{23}$ Seorang gembala bertanggungjawab atas pengelolaan sebuah lembaga gereja. Seorang pemimpin bertanggungjawab atas keseluruhan jalannya lembaga dan orangorang yang dipimpinnya. Diakui atau tidak, kegagalan sebuah organisasi adalah kegagalan sang pemimpinnya.

23 Bakhoh Jatmiko, "Optimalisasi Fungsi-Fungsi Jabatan Kepemimpinan Gerejawi Sebagai Salah Satu Perwujudan Pelayanan Yang Holistik," Sanctum Domine: Jurnal Teologi (2020). 
Keempat, berdasarkan pengamatan, hasil penelitian dan informasi yang didapat dari para informan, peneliti menemukan bahwa kepemimpinan Bapak Gembala cenderung otoriter. Pemimpin (gembala) mendominasi tindakan pemuridan kepada jemaat (lihat Tabel 2 di atas), bukan hanya itu bahkan kepada para pengurusnya juga. Menurut pengamatan peneliti, pengurus bersikap pasif, hanya menjalankan instruksi pemimpin. Pemikiran dan pengaturan operasional urusan gereja, semua datangnya dari pemimpin langsung.

Seorang gembala seharusnya berhati hamba yang rendah hati dan setia. Seorang pelayan yang memiliki pengetahuan teologi yang benar dan memiliki hati yang dekat dengan Tuhan. ${ }^{24}$ Di kehidupan sehari-hari masih dijumpai pelayan Tuhan yang kehidupan rohaninya tidak beda jauh dengan jemaat biasa. Ini bisa disebabkan karena beliau belum mengerti hakikat dunia pelayanan dan hakikat menjadi seorang pelayan Tuhan. ${ }^{25}$ Seorang pemimpin rohani yang bersikap demikian, merupakan penghambat bagi kemajuan iman orang

24 Jelita Sihite, "Berteologi Dan Melayani," Kurios Volume 1, no. No.1 (2013): $67-75$.

25 H. Soekahar, Potret Pendeta Di Tengah-Tengah Masyarakat Pluralis Modern (Malang: Gandum Mas, 2002),35. yang dipimpinnya. ${ }^{26}$ Kepemimpinan Kristen berlandaskan kebenaran Alkitab, maka kepemimpinan yang otoriter dapat dikatakan tidak sejalan dengan ajaran Kristus. ${ }^{27}$ Seorang gembala seharusnya telah memahami tugas dan panggilan sebagai seorang pelayan Tuhan untuk menghindari adanya penyelewengan atau penyalahgunaan wewenang dalam menggembalakan dan memuridkan jemaatnya. Ia harus konsisten menjalankan tugasnya sesuai ajaran Kristus. ${ }^{28}$ Seorang guru adalah teladan bagi muridnya. Dia dapat mengubah pandangan, sikap dan hidup muridnya. Demikian juga halnya dengan seorang pemimpin gereja dan jemaat yang dipimpinnya, dia dapat dijadikan panutan hidup bagi jemaatnya. Seorang gembala seharusnya memiliki pribadi seperti Sang Guru Agung, Kristus. ${ }^{29}$

Kelima, penggembalaan jemaat disabilitas dan non disabilitas tidak berbeda jauh. Temuan penelitian

26 Bernike Sihombing, "Kepribadian Dan Kehidupan Hamba Tuhan Menurut 1 Timotius 3:1-13," Kurios Volume 2, no. No.1 (2014).

27 Kuncoro Condro, "Kepemimpinan Kerajaan Allah Berdasarkan Ucapan Bahagia Ajaran Yesus Kristus Matius 5:3-12," Sanctum Domine: Jurnal Teologi (2020).

28 Joko Santoso, "Pelayanan Hamba Tuhan Dalam Tugas Penggembalaan Jemaat," Sanctum Domine: Jurnal Teologi (2020).

29 Stephanus Hartoyo, "Yesus: Tuhan, Guru Dan Teladan Orang Percaya," Sanctum Domine: Jurnal Teologi (2019). 
mendapatkan data bahwa Ketujuh, hampir seluruh jemaat menggembalakan atau membina jemaat tuna netra (penyandang disabilitas), tidak berbeda dengan jemaat yang lainnya (non disabilitas). Demikian pula dengan cara penginjilan terhadap mereka. Cara perlakuan terhadap mereka tidak berbeda jauh menurut pengakuan informan yang selain gembala atau pengurus gereja, mereka juga penyandang disabilitas. Mereka memang ingin lebih dipahami berhubung karena keterbatasannya, tapi bukan berarti diistimewakan. Jadi ini mematahkan anggapan bahwa seorang tuna netra atau penyadang disabilitas lainnya adalah selalu orang-orang yang rapuh, tidak berdaya, tidak berguna dan selalu minta belas kasihan dari orang lain. Penyandang disabilitas harus mendapatkan hak yang sama dan perlakuan yang setara.

Keenam, bidang yang menjadi perhatian utama dan titik berat pemimpin dalam proses pemuridan di Gereja $M$ Malang adalah menekankan bidang misi dan condong melakukan mission trip, sesuai dengan visi gereja tersebut. Mission trip di Gereja M Malang dipandang oleh pemimpin gereja sebagai suatu tindakan pemuridan dengan mengutamakan pemberdayaan yang dikhususkan bagi jemaat penyandang disabilitas. Gereja M Malang berjemaat di gereja lain juga. Ini menunjukkan bahwa kurangnya pemberdayaan di gereja lokal mereka masing-masing. Gereja adalah sebuah realitas, makna gereja yang paling utama adalah suatu peristiwa, suatu kenyataan, suatu peristiwa sejarah, sehingga mengajar dan membina para murid Kristus melalui pemuridan yang sesuai ajaran Kristus sangatlah penting, karena akan mempengaruhi cara hidup mereka. ${ }^{30}$ Pemuridan seorang jemaat juga memiliki makna memberdayakan potensi yang ada di dalam dirinya. Talenta yang dimilikinya harus diaktualisasikan dengan keterlibatannya dengan dunia pelayanan sehingga menjadi berkat bagi sesama. Pemberdayaan jemaat berarti pemuridan yang aktif dan hidup. Sebuah gereja yang melakukan pemuridan tanpa pemberdayaan jemaatnya, sama saja dengan berjalan di tempat. Pemuridan tanpa pemberdayaan jemaatnya hanya sekedar mengajarkan teori. Pemuridan yang tanpa praktik dalam kehidupan sehari-hari, menghasilkan iman yang tidak bertumbuh. Alkitab mengatakan bahwa: "Demikian juga halnya dengan iman: Jika iman itu tidak disertai Menghadirkan Kerajaan Allah Di Bumi," Sanctum Domine: Jurnal Teologi (2019). 
perbuatan, maka iman itu pada

hakekatnya adalah mati." (Yak 2:17)

Dari hasil analisis maka dibuat

diagram tentang cara-cara pemuridan

jemaat yang dilakukan di Gereja M

Malang (Lihat Gambar 1: Diagram

Persentase Frekuensi Cara-Cara

Pemuridan Jemaat di Gereja M Malang). 


\section{Gambar 1:}

\section{Diagram Persentase Frekuensi Cara-Cara Pemuridan Jemaat Gereja M Malang}

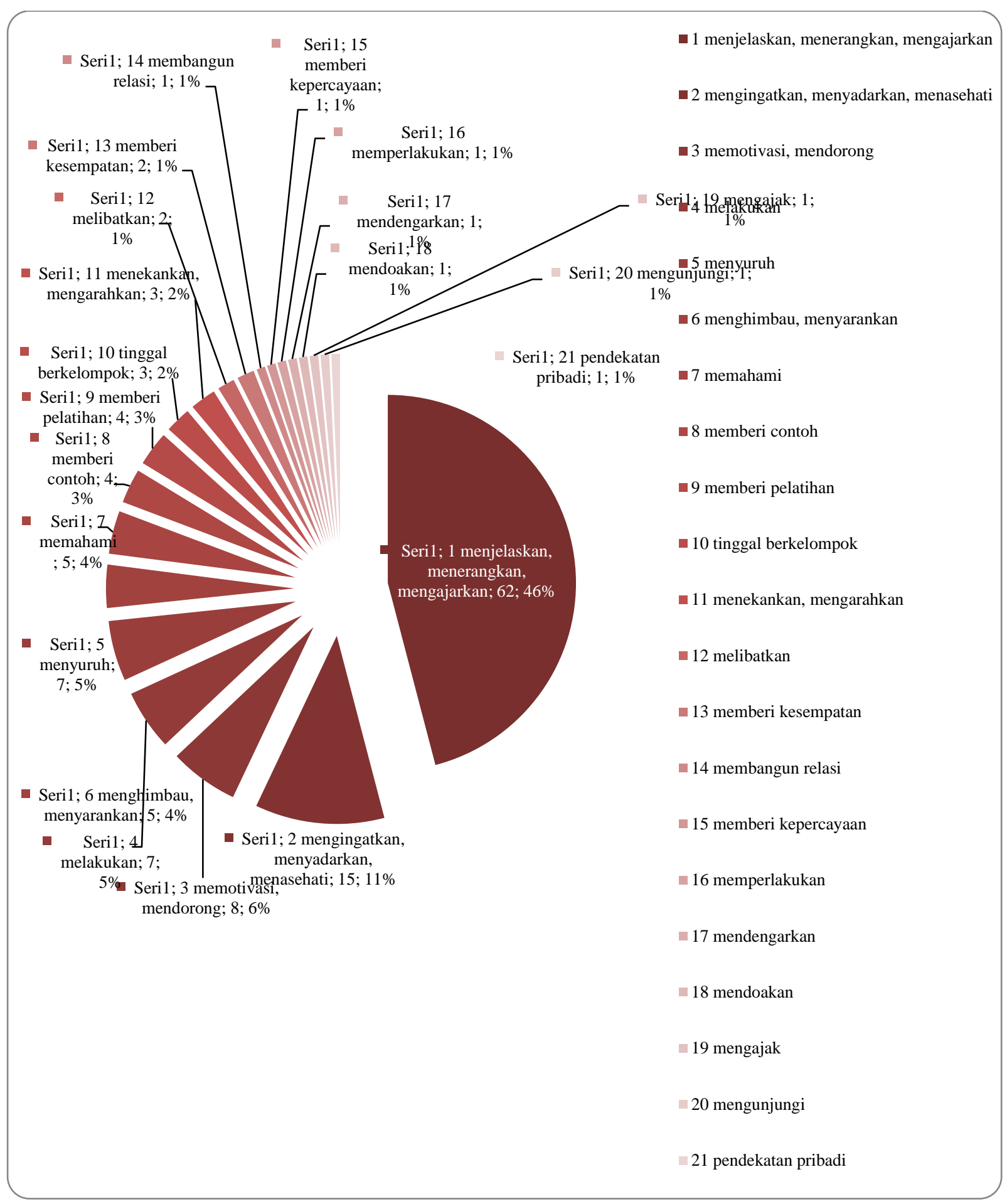




\section{KESIMPULAN}

Dari temuan hasil penelitian di lapangan, disimpulkan bahwa model pemuridan bagi jemaat penyandang disabilitas di Gereja M Malang adalah kombinasi dari pembekalan melalui pengajaran nilai-nilai Kristen, pembinaan sikap, serta pemberdayaan jemaatnya; dengan memberikan porsi yang paling besar pada pemberdayaan. Gembala mengutamakan pemberdayaan jemaatnya dengan melakukan mission trip.

Temuan penelitian mengenai model pemuridan di Gereja M Malang ini bisa diimplementasikan bagi semua jemaat di gereja lain, tidak hanya khusus bagi komunitas jemaat penyandang disabilitas saja.

Peneliti menyimpulkan bahwa model pemuridan di Gereja M Malang belum menjawab kebutuhan jemaat penyandang disabilitas secara holistik. Dengan kajian ini, harapannya menjadi bahan pemikiran bagi para peneliti dimasa yang akan datang. Strategi, pendekatan serta model pemuridan yang efektif perlu dikembangkan untuk menolong para disabilitas.

\section{DAFTAR PUSTAKA}

A, Geminastiti Purinami, Nurliana Cipta Apsari, and Nandang Mulyana. "Penyandang Disabilitas Dalam
Dunia Kerja." Focus: Jurnal Pekerjaan Sosial (2019).

Bising, Yoseph P. "Kebenaran Tentang Hidup Produktif." Kurios Volume: 2, no. No.1 (2014): 57-61.

Blair, Tony. Improving The Life Chances Of Disabled People, 2005.

Budiman, Arif. Teori Pembangunan Dunia Ketiga. Jakarta: PT Gramedia Pustaka Utama, 2000.

Condro, Kuncoro. "Kepemimpinan Kerajaan Allah Berdasarkan Ucapan Bahagia Ajaran Yesus Kristus Matius 5:3-12." Sanctum Domine: Jurnal Teologi (2020).

Frederick, Thomas V. "Discipleship and Spirituality from a Christian Perspective." Pastoral Psychology (2008).

Hartono, Handreas. "Pentingnya Kurikulum Dalam Pemuridan." Kharismata: Jurnal Teologi Pantekosta (2020).

Hartoyo, Stephanus. "Yesus: Tuhan, Guru Dan Teladan Orang Percaya." Sanctum Domine: Jurnal Teologi (2019).

I Putu Ayub Darmawan. "Jadikanlah Murid: Tugas Pemuridan Dan Gereja Menurut Matius 28:18-20." Evangelikal: Jurnal Teologi Injili dan Pembinaan Warga Jemaat (2019).

Ife, Jim, and Frank Tesoriero. Community Development. Yogyakarta: Pustaka Belajar, 2008.

Isdaryanto, Eta Yuni Lestari.Slamet Sumarto.Noorochmat. "Pemenuhan Hak Bagi Penyandang Disabilitas Di Kabupaten Semarang Melalui Implementasi Convention on the Rights of Persons With Disabillities (Cprd) Dalam Bidang Pendidikan." Integralistik (2017). 
Jatmiko, Bakhoh. "Optimalisasi FungsiFungsi Jabatan Kepemimpinan Gerejawi Sebagai Salah Satu Perwujudan Pelayanan Yang Holistik." Sanctum Domine: Jurnal Teologi (2020).

Kompasiana. "Disabilitas Merupakan Sebab Dan Akibat Dari Kemiskinan." REP, 2014. http://sosbud.kompasiana.com/2014/ 06/14/disabilitas-merupakan-sebabdan-akibat-dari-kemiskinan658544.html.

Likumahwa, George Marthen, John A Titaley, and Steve Gaspersz. "Keluar Dari Kemiskinan: Studi Pembangunan Dan Pemberdayaan Jemaat Di Dusun Siahari, Kecamatan Seram Utara Timur." Arumbae: Jurnal Ilmiah Teologi dan Studi Agama (2020).

Moleong, Lexy J. Metodologi Penelitian Kualitatif. Bandung: PT Remaja Rosdakarya, 2012.

Moniaga, Sandra, and Newbie. "Disabilitas, HAM, Dan Gereja." Last modified 2018. https://www.hidupkatolik.com/2018 /10/31/28330/disabilitas-ham-dangereja.

Organization, International Labour (ILO). "Inklusi Penyandang Disabilitas Di Indonesia." Jurnal Refleksi Hukum (2017).

Priana, I Made. "Misi Gereja Menghadirkan Kerajaan Allah Di Bumi." Sanctum Domine: Jurnal Teologi (2019).

Riwukore, Jefirstson Richset, Fellyanus Habaora, Yohanes Susanto, and Hilda Manafe. "Persepsi Publik Terhadap Penyandang Disabilitas Di Kota Kupang Provinsi Nusa Tenggara Timur." Journal of Chemical Information and Modeling (2019).
Santoso, Joko. "Pelayanan Hamba Tuhan Dalam Tugas Penggembalaan Jemaat." Sanctum Domine: Jurnal Teologi (2020).

Saptenno, Kritsno. "Mewariskan Keberpihakan Lewat Musik: Suatu Interpretasi Teologis Yang Berpihak Kepada Penyandang Disabilitas Terhadap Lagu "Fly."' KENOSIS: Jurnal Kajian Teologi (2019).

Sihite, Jelita. "Berteologi Dan Melayani." Kurios Volume 1, no. No.1 (2013): 67-75.

Sihombing, Bernike. "Kepribadian Dan Kehidupan Hamba Tuhan Menurut 1 Timotius 3:1-13." Kurios Volume 2, no. No.1 (2014).

Soekahar, H. Potret Pendeta Di TengahTengah Masyarakat Pluralis Modern. Malang: Gandum Mas, 2002.

Soesilo, Yushak. "Pentakostalisme Dan Aksi Sosial: Analisis Struktural Kisah Para Rasul 2:41-47." DUNAMIS: Jurnal Teologi dan Pendidikan Kristiani (2018).

Spradley, James P. Participant Observation. New York: Holt, Rinehart and Winston, 1980.

Subekti, Tri. "Pemuridan Misioner Dalam Menyiapkan Perluasan Gereja Lokal." EPIGRAPHE: Jurnal Teologi dan Pelayanan Kristiani (2019).

Widhawati, Monica Kristiani, Meilanny Budiarti Santoso, and Nurliana Cipta Apsari. "Ruang Kerja Inklusif Bagi Tenaga Kerja Dengan Disabilitas Fisik." Empati: Jurnal Ilmu Kesejahteraan Sosial (2020).

Widinarsih, Dini. "Penyandang Disabilitas Di Indonesia :" Jurnal Ilmu Kesejahteraan Sosial (2019).

Zaluchu, Sonny Eli. "Strategi Penelitian Kualitatif Dan Kuantitatif Di Dalam 
Penelitian Agama." Evangelikal:

Jurnal Teologi Injili dan Pembinaan Warga Jemaat (2020). 
34 | SANCTUM DOMINE: Jurnal Teologi, vol. 10, no. 1 (2020) 